\title{
Detection of Toxoplasma gondii in a Eurasian Badger (Meles meles) Living in Wildlife Areas of Izmir, Turkey
}

\author{
İzmir Doğal Hayatında Yaşayan bir Avrasya Porsuğunda (Meles meles) Toxoplasma gondï’ nin
}

Saptanmasi

\section{Muhammet Karakavuk (1D, Duygu Aldemir² (D), Esra Atalay Şahar ${ }^{1}$ (D), Hüseyin Can $^{3}$ (D) , Hüseyin

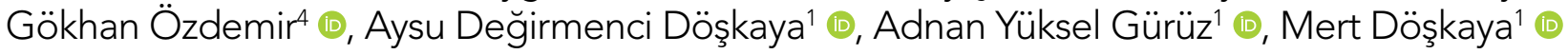

\author{
1Department of Parasitology, Ege University School of Medicine, İzmir, Turkey \\ 2Department of Internal Medicine, Uludağ University Institute of Health Sciences, Faculty of Veterinary Medicine, Bursa, Turkey \\ ${ }^{3}$ Department of Biology, Molecular Biology Section, Ege University Faculty of Science, Izmir, Turkey \\ ${ }^{4}$ The Protection and Development, Union of Izmir Bird Paradise, İzmir, Turkey
}

Cite this article as: Karakavuk M, Aldemir D, Atalay Şahar E, Can H, Özdemir HG, Döşkaya Değirmenci A, et al. Detection of Toxoplasma gondii in a Eurasian Badger (Meles meles) Living in Wildlife Areas of Izmir, Turkey. Turkiye Parazitol Derg 2018; 42(3): 237-9.

\section{ABSTRACT}

Toxoplasma gondii is an obligatory intracellular protozoon parasite that causes toxoplasmosis in humans and all warm-blooded animals. In this study, we aimed to investigate the presence of T. gondii DNA in a Eurasian badger (Meles meles) that was found dead in the wildlife area of Izmir. According to the results of real time polymerase chain reaction, $T$. gondii REP gene was found to be positive in the Eurasian badger brain homogenate. In conclusion, Eurasian badger, a known carnivore, can be a potential source of toxoplasmosis in the natural settings of Izmir, Turkey.

Keywords: Eurasian badger, Meles meles, PCR, Toxoplasma gondii, Turkey

Received: 08.02.2018

Accepted: 10.04 .2018

\section{Öz}

Toxoplasma gondii, insanlarda ve tüm sıcakkanlı hayvanlarda toksoplazmozise neden olan zorunlu hücre içi protozoon bir parazittir. Bu çalışmada, İzmir'in yaban hayatında ölü olarak bulunan bir Avrasya porsuğunda (Meles meles) T. gondii DNA varlığının araştırılması amaçlanmıştır. Real time Polimeraz Zincir Reaksiyonu (PZR) sonucuna göre T. gondii REP geni Avrasya porsuğunun beyin homojenatında pozitif bulunmuştur. Sonuçta önemli bir etobur olan Avrasya porsuğunun İzmir'in doğal çevresinde potansiyel bir toksoplazmoz kaynağı olabileceği gösterilmiştir.

Anahtar Kelimeler: Avrasya porsuğu, Meles meles, PZR, Toxoplasma gondii, Türkiye

Geliş Tarihi: 08.02.2018

Kabul Tarihi: 10.04.2018

\section{INTRODUCTION}

Toxoplasma gondii is an obligatory intracellular protozoon parasite that causes toxoplasmosis in humans and all warm-blooded animals (1). T. gondii has a complex life cycle including sexual and asexual reproductive phases. Felines are the definitive host that oocyst formation occurs through sexual reproduction. Also, tachyzoite and tissue cyst (bradyzoites) production occurs through asexual reproduction in felines and other intermediate hosts such as mammals and birds (1). Oocysts which are highly resistant to environmental conditions and meat containing tissue cysts are the main factors that spread the infection among wild animals $(2,3)$. The Eurasian badger (Meles meles) belonging to the family Mustelidae lives in Europe and Eurasia located in the northern hemisphere. Although the Eurasian badger is classified as a carnivore; these animals also feed on a wide variety of plants (4). In some previous studies conducted in Europe, toxoplasmosis was detected in Eurasian badger using serological methods and/or conventional or nested polymerase chain reaction (PCR) methods (5-10). In this study,

This study has been presented at the International Symposium on Parasitic Zoonoses held in Antalya, Turkey, between November 16 and $20,2016$. Bu çalışma 16-20 Kasım 2016 tarihleri arasında Türkiye, Antalya'da düzenlenen International Symposium on Parasitic Zoonoses'da sunulmuştur. Address for Correspondence / Yazışma Adresi: Hüseyin Can E.mail: huseyin.can@ege.edu.tr DOI: $10.5152 /$ tpd.2018.5884 

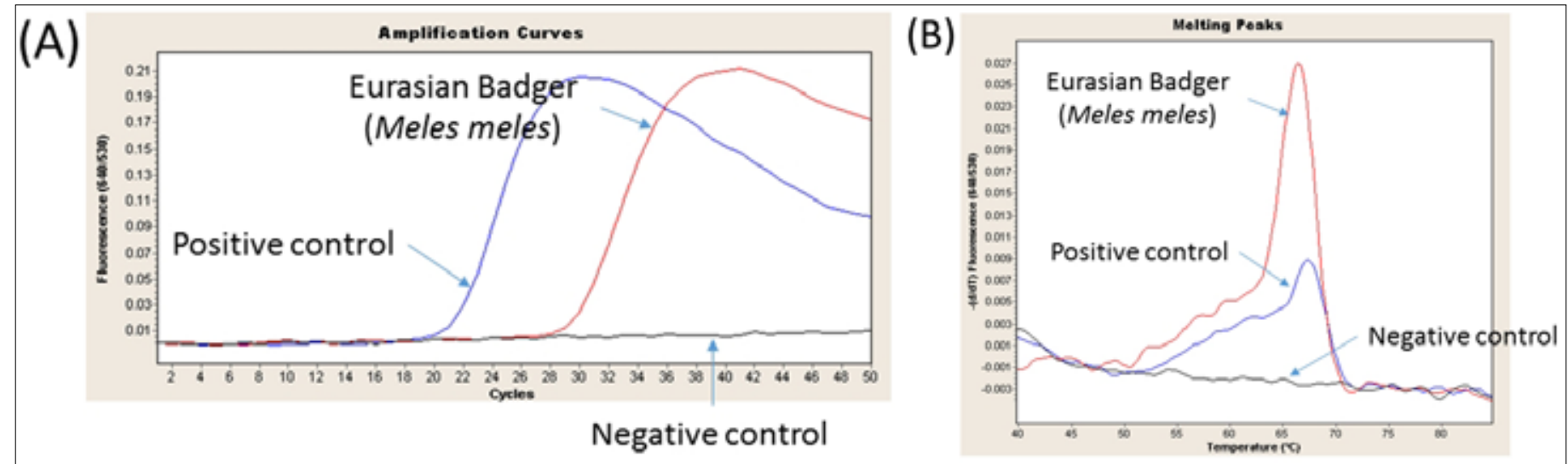

Figure 1. a, b. Results of real-time PCR targeting T. gondii REP gene (a) Quantification and (b) Melting Curve Analysis

using real-time PCR, we aimed to investigate the presence of $T$. gondii in a Eurasian badger that was found dead in the wildlife area of Izmir located in the Aegean region of Turkey.

\section{CASE REPORT}

A Eurasian badger was found dead in wild life of Izmir located in the Aegean region of Turkey and was brought to Izmir Natural Life Park. On external examination, no pathological sign was detected on the body, fur, nails, and eyes. Only ticks were detected on the skin of the animal. Furthermore, no macroscopic abnormality was observed on necropsy of the abdomen and chest cavity. All experiments were performed under the instructions and approval of the Institutional Animal Care and Use Committee of Ege University for animal ethical norms (Permit number: 201416).

To investigate the presence of $T$. gondii in the Eurasian badger, brain tissue was homogenized as previously described (11). Briefly, the brain was removed by opening the skull using a costatome and was homogenized in sterile $0.9 \% \mathrm{NaCl}$ using a blender (Waring, USA). During the homogenization process, $125 \mathrm{~mL} 0.9 \%$ $\mathrm{NaCl}$ was used for $10 \mathrm{~g}$ tissue. After homogenization, $0.5 \mathrm{~g}$ of trypsin (BD sciences, USA) was added to the homogenate and incubated at $37^{\circ} \mathrm{C}$ for 75 min using an incubator shaker (New Brunswick, USA). Later, the homogenate was filtered into a 50 $\mathrm{ml}$ falcon tube using two-layered sterile gauze and was centrifuged for $15 \mathrm{~min}$ at $910 \mathrm{~g}$. After this process, the supernatant was discarded and the pellet was washed two more times with $0.9 \%$ $\mathrm{NaCl}$. Following the last centrifugation, the supernatant was discarded, and DNA extraction from the pellet was performed using QIAamp DNA mini kit (Qiagen, USA).

T. gondii REP gene (Genebank Accession no: AF146527) was amplified using real-time PCR as previously described (11). To amplify a 134 bp gene fragment, the primers ( $F$ : 5'-AGGCGAGGGTGAGGATGA-3' and R: 5'-TCGTCTCGTCTGGATCGCAT-3') and hybridization probes [5'-GCCGGAAACATCTTCTCCCTCTCC-3'-FL and 5'-640-CTCTCGTCGCTTCCCAACCACG-3' (Metabion, Germany)] were used. Real-time PCR was performed using LightCycler 1.5 Real Time instrument with LightCycler software, version 4.1 (Roche, Germany). T. gondii genomic DNA, which was diluted from $10^{6} / \mathrm{mL}$ to $10^{1} / \mathrm{mL}$, and distilled water were used as positive and negative controls, respectively. According to the quantification and melting curve analysis (Figure 1), T. gondii REP gene was positive in the Eurasian badger brain homogenate.

\section{DISCUSSION}

In Turkey, it is well known that badgers particularly inhabit the regions of Adana, Adapazarı, Ankara, Aydın, Balıkesir, Bingöl, Burdur, Denizli, Eskişehir, Isparta, Kahramanmaraş, Konya, Mersin, Muğla, Ordu, Trabzon, and Zonguldak. Furthermore, badgers live throughout Anatolia as well as Thrace region of Turkey and can live up to an altitude of $2000 \mathrm{~m}$ (12). In this study, a dead Eurasian badger was found in the wildlife area of Bornova-Izmir located in the Aegean region of Turkey. It was thought that investigations on this animal may provide new data for those who work in the field of animal ecology. On the other hand, the presence and/or frequency of $T$. gondii in various wild animals is currently being investigated to reveal the animal species that helps spread the parasite and to determine the potential source of toxoplasmosis in nature. The presence of T. gondii has been detected in the Eurasian badger in previous studies conducted in UK, Spain, Portugal, Slovakia, and Poland; these studies have shown the presence of anti-Toxoplasma antibodies and/or used conventional or nested PCR methods to show the presence of T. gondii (5-10). The presence of $T$. gondii has been reported in various wild animals belonging to the family Mustelidae, such as mink (Mustela vison), river otters (Lontra canadensis), southern sea otters (Enhydra lutris nereis), black-footed ferrets (Mustela nigripes), stone marten (Martes foina), pine marten (Martes martes), ferret (Mustela putorius furo), Eurasian otter otters (Lutra lutra), and polecat (Mustela putorius), using microscopy, in vitro cultivation, and serological methods $(6,13-16)$.

\section{CONCLUSION}

In this study, T. gondii REP gene was detected for the first time in a Eurasian badger that is found in Turkey using real-time PCR. This result showed that $T$. gondii is capable of infecting the Eurasian badger and causing chronic infection. Since chronically infected animals are accepted as a potential source of toxoplasmosis, the Eurasian badger can also be a source for the transmission of toxoplasmosis in the natural setting of Izmir, Turkey. 
Peer-review: Externally peer-reviewed.

Author Contributions: Concept - M.D., M.K.; Design - M.K., M.D., H.C.; Supervision - M.D., A.D.D., Y.G.; Resources - M.K., E.A.Ş., H.G.Ö., D.A.; Materials - M.K., M.D., H.G.Ö., D.A.; Data Collection and/or Processing - M.K., H.G.Ö., D.A., H.C., A.D.D.; Analysis and/or Interpretation - M.D., H.C., Y.G., A.D.D.; Literature Search - M.K., E.A.Ş., H.C., A.D.D.; Writing Manuscript - M.K., H.C., M.D.; Critical Review - Y.G., A.D.D., H.C., M.D.; Other - M.K., E.A.Ş., D.A., H.G.Ö.

Conflict of Interest: Authors have no conflicts of interest to declare.

Financial Disclosure: The authors declared that this study has received no financial support.

Hakem Değerlendirmesi: Dış bağımsız.

Yazar Katkıları: Fikir - M.D., M.K.; Tasarım - M.K., M.D., H.C.; Denetleme - M.D., A.D.D., Y.G.; Kaynaklar - M.K., E.A.Ş., H.G.Ö., D.A.; Malzemeler - M.K., M.D., H.G.Ö., D.A.; Veri Toplanması ve/veya İşlemesi M.K., H.G.Ö., D.A., H.C., A.D.D.; Analiz ve/veya Yorum - M.D., H.C., Y.G., A.D.D.; Literatür Taraması - M.K., E.A.Ş., H.C., A.D.D.; Yazıyı Yazan - M.K., H.C., M.D.; Eleştirel İnceleme - Y.G., A.D.D., H.C., M.D.; Diğer - M.K., E.A.Ş., D.A., H.G.Ö.

Çıkar Çatışması: Yazarlar çıkar çatışması bildirmemişlerdir.

Finansal Destek: Yazarlar bu çalışma için finansal destek almadıklarını beyan etmişlerdir.

\section{REFERENCES}

1. Montoya JG, Liesenfeld O. Toxoplasmosis. Lancet 2004; 363: 196576. [CrossRef]

2. Dubey JP. Toxoplasmosis of animals and humans. Second edition. CRC press. 2009. Boca Raton, USA. [CrossRef]

3. Muz MN, Kılınç ÖO, İşler CT, Altuğ E, Karakavuk M. Molecular diagnosis of Toxoplasma gondii and Neospora caninum in brain tissues of some wild birds. Kafkas Üniversitesi Veteriner Fakültesi Dergisi 2015; 21: 173-8.

4. Kruuk H, Parish T. Feeding specialization of the European badger Meles meles in Scotland. The Journal of Animal Ecology 1981; 77388. [CrossRef]
5. Anwar A, Knaggs J, Service KM, McLaren GW, Riordan P, Newman C, et al. Antibodies to Toxoplasma gondii in Eurasian badgers. J Wildlife Dis 2006; 42: 179-81. [CrossRef]

6. Sobrino R, Cabezón O, Millán J, Pabón M, Arnal MC, Luco DF, et al. Seroprevalence of Toxoplasma gondii antibodies in wild carnivores from Spain. Veterinary Parasitology 2007; 148: 187-92. [CrossRef]

7. Lopes AP, Sargo R, Rodrigues M, Cardoso L. High seroprevalence of antibodies to Toxoplasma gondii in wild animals from Portugal. Parasitol Res 2011; 108: 1163-9. [CrossRef]

8. Burrells A, Bartley PM, Zimmer IA, Roy S, Kitchener AC, Meredith A, et al. Evidence of the three main clonal Toxoplasma gondii lineages from wild mammalian carnivores in the UK. Parasitol 2013; 140: 176876. [CrossRef]

9. Turčeková L, Hurníková Z, Spišák F, Miterpáková M, Chovancová B. Toxoplasma gondii in protected wildlife in the Tatra National Park (TANAP), Slovakia. Ann Agric Environ Med 2014; 21: 235-8. [CrossRef]

10. Kornacka A, Cybulska A, Bień J, Goździk K, Moskwa B. The usefulness of direct agglutination test, enzyme-linked immunosorbent assay and polymerase chain reaction for the detection of Toxoplasma gondii in wild animals. Vet Parasitol 2016; 15: 85-9. [CrossRef]

11. Can H, Döşkaya M, Ajzenberg D, Özdemir HG, Caner A, İ SG, et al. Genetic characterization of Toxoplasma gondii isolates and toxoplasmosis seroprevalence in stray cats of İzmir, Turkey. PLoS One 2014; 15: e104930. [CrossRef]

12. Özen AS, Uluçay i. Ecological, biological and taxonomical characteristics of Meles meles Linnaeus, 1758 (Mammalia: Carnivora) in Kütahya. Dumlupınar Üniversitesi Fen Bilimleri Enstitüsü Dergisi 2010; 21: 9-20.

13. Tocidlowski ME, Lappin MR, Sumner PW, Stoskopf MK. Serologic survey for toxoplasmosis in river otters. J Wildlife Dis 1997; 33: 64952. [CrossRef]

14. Cole RA, Lindsay DS, Howe DK, Roderick CL, Dubey JP, Thomas NJ، et al. Biological and molecular characterizations of Toxoplasma gondii strains obtained from southern sea otters Enhydra lutris nereis. J Parasitol 2000; 86: 526-30. [CrossRef]

15. Frank RK. An outbreak of toxoplasmosis in farmed mink Mustela vison. Journal of Veterinary Diagnostic Investigation 2001; 13: 245-9. [CrossRef]

16. Burns R, Williams ES, O'toole D, Dubey JP. Toxoplasma gondii infections in captive black-footed ferrets Mustela nigripes, 1992-1998, clinical signs, serology, pathology, and prevention. J Wildlife Dis 2003; 39: 787-97. [CrossRef] 